\title{
Sincretismo e Resistência: o caso africano da igreja Oruuano
}

Josué Tomasini Castro O trabalho que se segue é resultado da reflexão sobre um problema de campo, (PPGAS/UnB) iluminado por considerações histórias e etnográficas que, ao fim, procuram contribuir para o melhor entendimento de processos sincréticos. Na prática (do texto) isso significa que farei uso tanto dos desdobramentos históricos como das minhas experiências de pesquisa para melhor entender uma frase ouvida em campo que, por sua vez, é reveladora de certo aspecto dos estudos sobre o sincretismo'.

A experiência de pesquisa à qual me refiro foi um campo preliminar realizado entre dezembro de 2005 e março de 2006 em Okondjatu, um vilarejo predominantemente herero situado ao norte da Namíbia, sul do continente africano. Okondjatu é um vilarejo central em uma região não muito central da Namíbia. Isso significa, em outras palavras, que sua população total está entre oitocentos e mil habitantes. Além disso, Okondjatu é o único local da região que possui energia elétrica (isto apenas próximo à única estrada que corta o vilarejo), pequenos bares e mais de uma igreja cristã fixa e com cultos mais ou menos regulares.

Logo nos primeiros dias em campo o universo religioso do vilarejo me chamou a atenção por ser um tanto movimentado (três templos cristãos) e pelo fato de que as pessoas comumente conversavam sobre essas questões, algumas possuindo visões muito particulares sobre o cristianismo. A igreja Oruuano que trago para análise neste ensaio faz parte desses itinerários. Conhecida como a apropriação herero do cristianismo - ou seja, como uma "igreja nativa" -, ela possui contornos fortemente luteranos devido às influências missionárias que estiveram presentes na região. Mas, como "igreja nativa", ela abarca também, dentro de seu repertório, elementos do conhecimento tradicional herero: o Fogo Sagrado $(\text { Okuruwo })^{2}$.

Assim, o sincretismo que percebo nessa igreja - e que explorarei neste texto - se expressa na possibilidade de que uma única igreja cristã possua dentro do seu conhecimento religioso elementos tanto do cristianismo como do Fogo Sagrado. Meu principal esforço será, após uma breve exploração do conceito de sincretismo, mostrar historicamente como esse processo de sincretização foi, de fato, o resultado de um processo anterior de resistência a uma situação colonial. 
apesar de o uso do cristianismo como "qualificador" dessa igreja ser de uso êmico, a noção de sincretismo por mim empregada não é um "conceito nativo", ou seja, não é "um símbolo poderoso a partir do qual as pessoas elaboram suas identidades sociais" (Trajano 1998). Assim, um membro da igreja Oruuano se diz "cristão", mas jamais "sincrético". Nesse sentido, o uso do termo sincretismo se dá como uma ferramenta do pesquisador para entender um processo que lhe é singular.

Ainda como inspiração introdutória, vale também um pequeno comentário de cunho metodológico. Minhas discussões etnográficas estão baseadas nas informações de um único interlocutor. Caspa é presbítero da igreja Oruuano em Okondjatu e membro da mesma por mais de trinta anos, possuindo, assim, um vasto conhecimento tanto do mundo herero como também dessa realidade cristã. Minha escolha de utilizá-lo como interlocutor central para a elaboração deste ensaio se deu pelo seu vasto conhecimento e interessantes comentários ${ }^{3}$.

Tomo, assim, as observações de Caspa como interpretações valiosas sobre o universo religioso herero, entendendo também que suas palavras não devem ser ingenuamente generalizadas, como que para desvendar o todo pela parte. Suas interpretações são valiosas para entender o desdobramento de processos sincréticos e as formas como os indivíduos elaboram seus discursos, dando-Ihes sentido 4 .

A religião, em termos gerais, foi um objeto privilegiado nas pesquisas antropológicas sobre os sistemas sociais de diferentes sociedades africanas. Seria necessário lembrar apenas alguns trabalhos de poucos antropólogos para perceber o papel central que este universo galgou nas análises de tais sociedades pelos olhos atentos - e certamente enviesados - de distintos antropólogos ${ }^{5}$. São ritos de iniciação, casamentos, ritos fúnebres, processos de cura, palavras proclamadas antes da realização de atividades específicas e importantes; isso sem falar na invocação dos ancestrais, bem como na presença dos mesmos através de corpos vivos ou ainda nas festas realizadas de tempos em tempos para conjurar os maus espíritos e agradar aos deuses. Agora, imaginemos os missionários europeus, recém chegados em um território de amplas dimensões, vastos campos, desertos, animais, homens e mulheres muitas vezes completamente nus, toda uma imagética substancialmente diferente daquela de suas vidas reservadas no "velho mundo". Podemos conjecturar que as primeiras coisas a lhes saltarem os olhos devem ter sido aquelas danças, gritos, possessões e ritos de iniciação, todos "visivelmente" desprovidos de qualquer lógica cristã. Quem poderiam ser aqueles deuses? Para quem clamavam aquelas pessoas?

Pensando a partir da sua lógica dual simplista e dialética, não seria difícil imaginar que aquilo que lhes era desconhecido e, à primeira vista, completamente diferente da vida cristã européia, fosse caracterizado como diabólico. Ora, se o que não é bom é mau e o que não é "de deus" é "do diabo", não havia dúvidas para aqueles missionários da tarefa a ser realizada naquele local: trazer libertação àqueles corações "presos pelo pecado".

Deste ponto imaginário, podemos supor, iniciou-se aquilo que para muitos seria um processo inevitável: uma aculturação ${ }^{7}$ - que, no limite do sentido reservado a ela neste artigo, é uma conversão - dos corações e mentes "nativas" a partir de processos coloniais que visavam implementar a "verdadeira religião" e o "espírito evoluído" europeu no lugar dos sistemas religiosos e sócio-culturais autóctones. Claro está, no entanto, que isso 
não foi um processo meramente religioso; a religião, na verdade, era apenas um dos braços - o direito, talvez daqueles "ocidentais" ansiosos em conquistar novos mundos (Elias 1993 e 1990). Voltando à nossa arena religiosa, seria difícil supor que durante todo o período colonial - da chegada dos missionários até a criação das primeiras igrejas lideradas por nativos "nativos" - as crenças africanas teriam sido simplesmente deixadas de lado por aqueles corações "convertidos" de suas práticas passadas; como se a crença cristã tivesse sido "inteiramente absorvida através de uma aculturação passiva" (Shaw \& Stewart 1994:20).

A transmissão (ou imposição) de novos significados sagrados - e sociais - não se dá como se os símbolos, suas devidas categorizações e as regras que os unem fossem entregues dentro de pequenos pacotes conceituais que, então, sem nenhuma modificação - "contaminação", como muitos clérigos e líderes religiosos preferem falar - seriam incluídos em uma nova realidade social e passariam a ser usufruídos por uma nova e distinta sociedade. Pelo contrário, os significados do presente - para invocar Marshall Sahlins - são construídos com os significados do passado: "nada pode garantir que sujeitos inteligentes e motivados, com interesses e biografias sociais diversas, utilizarão as categorias existentes das maneiras prescritas" (Sahlins 2003: 7, 180, 192).

Diante de uma situação de contato interétnico ou, mais exatamente, em uma "situação colonial" - tal como discute Georges Balandier (1955) - e/ou de "expansão nacional" - tal como analisam Roberto Cardoso de Oliveira (1981), Darcy Ribeiro (1970) e João Pacheco de Oliveira (1999), para citar alguns -, aqueles que possuem menor poder simbólico e físico sobre a situação e que, por isso, vivenciam a constante diabolização de suas crenças, tendem a reorganizar seu mundo simbólico de forma a sobreviver aos drásticos resultados de sua situação enquanto dominados ${ }^{9}$.

Poderíamos chamar a isso de "resistência cultural", ou mesmo de "contracultura" (Sahlins 1997), certo é, no entanto, que não é possível pensar tais situações como livres de manobras políticas. Tal como discute Wolfgang Kempf, antropólogo alemão, as ações na história "não ocorrem em espaços livres [das engrenagens] do poder" (Kempf 1994:118). Dessa forma podemos entender que os processos sincréticos em situações de contato interétnico estão sempre relacionados à manipulação de símbolos estrangeiros por um indivíduo ou grupo de indivíduos, criando assim artifícios para a manutenção e expansão de um determinado repertório social ou, neste caso, religioso ${ }^{10}$.

Ou seja, a identidade de um grupo, ou antes, a preservação, e talvez melhor, a continuação desse fluxo identitário-cultural é uma construção negociada. Ora, como o sincretismo, presumidamente, "faz parte da negociação de identidades e hegemonias em situações de conquista, comércio, migração, disseminação religiosa" e outras, a questão da resistência a um poder hegemônico não deve ser percebida unicamente como uma forma de destruir as estruturas de poder de determinada sociedade; ela é, mais importante que isto, uma incorporação de elementos exógenos a uma identidade já existente, o que é fundamental "para a preservação ou adaptação de uma organização social" (Oliveira 1999: 117) minoritária e dominada.

Assim, procurar-se-á compreender a igreja Oruuano como uma das reelaborações herero da crença cristã, o ponto culminante em que todas as demandas "nativas", não legítimas perante o aparato cristão, foram re-alocadas em um novo quadro que, tal como no caso das demais igrejas presentes no mercado religioso namibiense - e mais exatamente no universo herero -, foi objetivado à vista de todos, uma opção legítima entre outras.

O processo que entendo como essencial para a criação dessa igreja está, claramente, num plano de 
negociação de identidades e reforço da "tradição nativa" 12 a partir de uma tomada dos repertórios dominantes pelos dominados. Objetivar tais discursos de poder foi um passo importante para tentar recuperar os espaços perdidos para as forças coloniais (nas quais se incluem as forças proselitistas dos missionários europeus) ${ }^{13}$.

Seria difícil seguir com minhas argumentações e descrições sem explicitar sumariamente o que aqui é entendido como "processos sincréticos". Com muitas ressalvas é necessário elaborar um aporte teórico ao qual possamos nos reportar durante o restante do texto.

\section{SINCRETISMO}

O contato inter-religioso, as misturas, os empréstimos - e, para usar termos mais "modernos", os hibridismos, crioulismos e sincretismos - existem desde que a primeira idéia religiosa surgiu, desde que o homem olhou para o céu e resolveu dotá-lo de poder, ou mesmo desde o momento descrito por Marcel Mauss em que o homem, "depois de ter sido deus, povoou o mundo de deuses" (Mauss 2003:51). Essas relações de contato sempre estiveram presentes no mundo social humano: lahweh, o deus dos judeus, não foi o único a proibi-las; as civilizações dos tempos helênicos não foram as únicas a misturar diferentes religiões e culturas; tampouco foi Plutarco, filósofo grego, o único a refletir sobre isso (Ferrari 2003).

Este ensaio pretende abordar mais um desses contatos, explicar quais os princípios que regem essas relações em um contexto específico. Relações que se dão quando do contato de diferentes complexos de fé, nas extremidades de sistemas religiosos distintos, nas fronteiras da crença e da descrença. É preciso saber o que é isto que acontece quando culturas entram em contato, quando arranjos religiosos são modificados pela transformação do contexto histórico-social, por novas revelações da fé.

Desde as primeiras décadas do século passado, entre os antropólogos da escola culturalista, um dos resultados deste encontro passou a ser denominado sincretismo. Herskovits foi o primeiro a incorporar o termo aos debates antropológicos e, desde seus primeiros escritos, muito já foi debatido, criado e recriado. Diz-se, a respeito do sincretismo, que ele seria uma forma de reinterpretação, ou seja, "o processo pelo qual os antigos significados se adscrevem a novos elementos ou através do qual valores novos mudam a significação cultural das velhas formas" (Herskovits 1973:375-6). Foi dito também que ele é "a expressão da dinâmica da religião" (Rudolph 2005:79), e ainda que ele acontece quando "dois ou mais cenários de metáforas religiosas estão disponíveis aos crentes, que então podem combiná-las de várias formas" (Droogers 2005:219).

Uma tendência atual dos estudos sobre sincretismo - na qual este trabalho se inscreve - tem sido pontuar a agência dos indivíduos envolvidos em tais processos bem como a política dessas relações, entendendo o sincretismo menos como uma tentativa de sobrevivência que como um influxo "comum" dos sistemas sociais de manter e recriar certas identidades que, entende-se, nunca estiveram livres de contatos exógenos. Assim, tem-se que as pessoas são "capazes de adaptar e mudar, e ainda assim ter sucesso em manter suas identidades" (Droogers \& Greenfield 2001:12).

Peter Berger afirma, em relação à definição de conceitos em ciências socais, que "a elucidação parece o caminho mais desejável" (Berger 1985:182) para evitar imprecisões e malentendidos na apreciação de discussões acadêmicas (especialmente aquelas que mesclam teoria e etnografia) ${ }^{14}$. Parece desejável então clarear meu ponto. 
Com todas as ressalvas necessárias, defendo aqui o uso de sincretismo tal como o entende Pierre Sanchis, como uma "tendência a utilizar relações apreendidas no mundo do outro para ressemantizar o seu próprio universo" (Sanchis 1994:6-7). Acrescentemos nosso viés "político" e veremos essa ressemantização também como uma tendência a reforçar uma identidade e objetivar demandas de legitimação perante um poder dominador.

Isso não significa, vale ressaltar ainda uma vez, perceber os sincretismos meramente como uma "política contra-hegemônica para burlar um poder dominante". Antes, como destacam Charles Stewart e Rosalind Shaw,

“sincretismo pode ser (ou talvez apenas se pareça com) uma forma de resistência porque práticas hegemônicas nunca são inteiramente absorvidas através de uma aculturação passiva; no limite, esta incorporação envolve algum tipo de transformação, algum tipo de desconstrução e reconstrução que a converterá em significados e práticas de um grupo" (Stewart \& Shaw 1994:20).

Feitos esses comentários introdutórios é possível adentrar as análises do trabalho de campo sobre o qual este trabalho ensaio está firmado, sendo já possível entender algumas questões que permeiam as racionalizações do pesquisador, quais sejam: como se articulam os movimentos de resistência "nativa" em meio a processos de colonização, e como funciona o sincretismo enquanto catalisador - e não destruidor - de uma identidade?

Tal como afirma Droogers (2005:219), o sincretismo pode apenas acontecer se dois ou mais "cenários de metáforas religiosas" estiverem disponíveis a um certo grupo de pessoas para serem apropriados dentro de seus discursos - neste caso, de fé, devoção, cura, profecia etc. Por isso, ao pretender estudar alguns aspectos de uma dessas ocorrências é preciso definir que metáforas são essas que, estando postas diante de um grupo de fiéis, foram apropriadas, sincretizadas, ou ainda, ressemantizadas dentro de universos religiosos distintos.

O escopo deste trabalho, já disse, está baseado na criação de uma igreja - a igreja Oruuano - e no entendimento desta, por minha parte, como uma criação sincrética motivada por certa defesa de uma tradição - e não devemos esquecer o que Sahlins destaca para a compreensão dos "movimentos culturalistas contemporâneos": "a defesa de uma tradição implica alguma consciência; a consciência da tradição implica alguma invenção; a invenção da tradição implica alguma tradição" (1997b:136). Assim, analisando o fenômeno a partir do conceito de sincretismo aqui empregado, é necessário expor os elementos que, acredita-se, foram ressemantizados pelos fiéis desta igreja, quais sejam: aqueles do Fogo Sagrado (que será agora exposto de forma sumária) e da doutrina cristã (da qual trataremos durante a análise histórica a ser realizada). 


\section{O FOGO SAGRADO}

O "conhecimento tradicional herero" que descreverei aqui é o que esse grupo denomina Fogo Sagrado ${ }^{16}$. Trata-se do local usado por um homem para que este possa entrar em contato com seus antepassados, entes respeitados e procurados por seus poderes de alçar vôos mais altos que os homens, por enxergarem além da visão dos homens e terem, assim, poder (tal como o termo é pensado em grande parte do continente: como autoridade) sobre o mundo visível ${ }^{17}$.

Cada linhagem herero possui ao menos um Fogo Sagrado, sendo que cada segmento dessa linhagem poderá também possuir um para si, que estará interligado ao primeiro. Local separado (mais do que sagrado) que fica sob o cuidado de um homem e de seu núcleo familiar (homem, mulher e seus filhos), deve encontrar-se entre a casa do "velho" - como são chamados os homens "especialistas" dessa tradição - e seu kraal - onde fica o seu gado. Ali são colocados alguns galhos no chão, e estes são cercados por três troncos pequenos de árvores, onde o filho se sentará para falar com seus pais.

O velho deve visitar o Fogo Sagrado diariamente, ao nascer e ao pôr do sol, quando os "espíritos dos mortos sopram as brasas" trazidas de dentro de sua casa e colocadas sob os galhos, levantando assim uma pequena fumaça que pode ser vista por todos no terreno, lembrando-os sempre de seus pais, já falecidos, e que hoje são os responsáveis pelo cuidado dos que ainda vivem. As brasas são retiradas da frente de um tronco que, colocado verticalmente no meio da casa do velho - a principal casa do terreno, onde residem apenas ele e sua mulher -, funciona como o contato entre o visível e o invisível, os vivos e os mortos. Diante dos galhos queimando vagarosamente, o homem conversa com seus ancestrais, presta-lhes reverência e garante, assim, o bem-estar de sua família.

Quando algum dos membros da família se encontrar enfermo ou com alguma dificuldade o "velho" deverá se dirigir ao Fogo Sagrado, onde procurará descobrir o que está

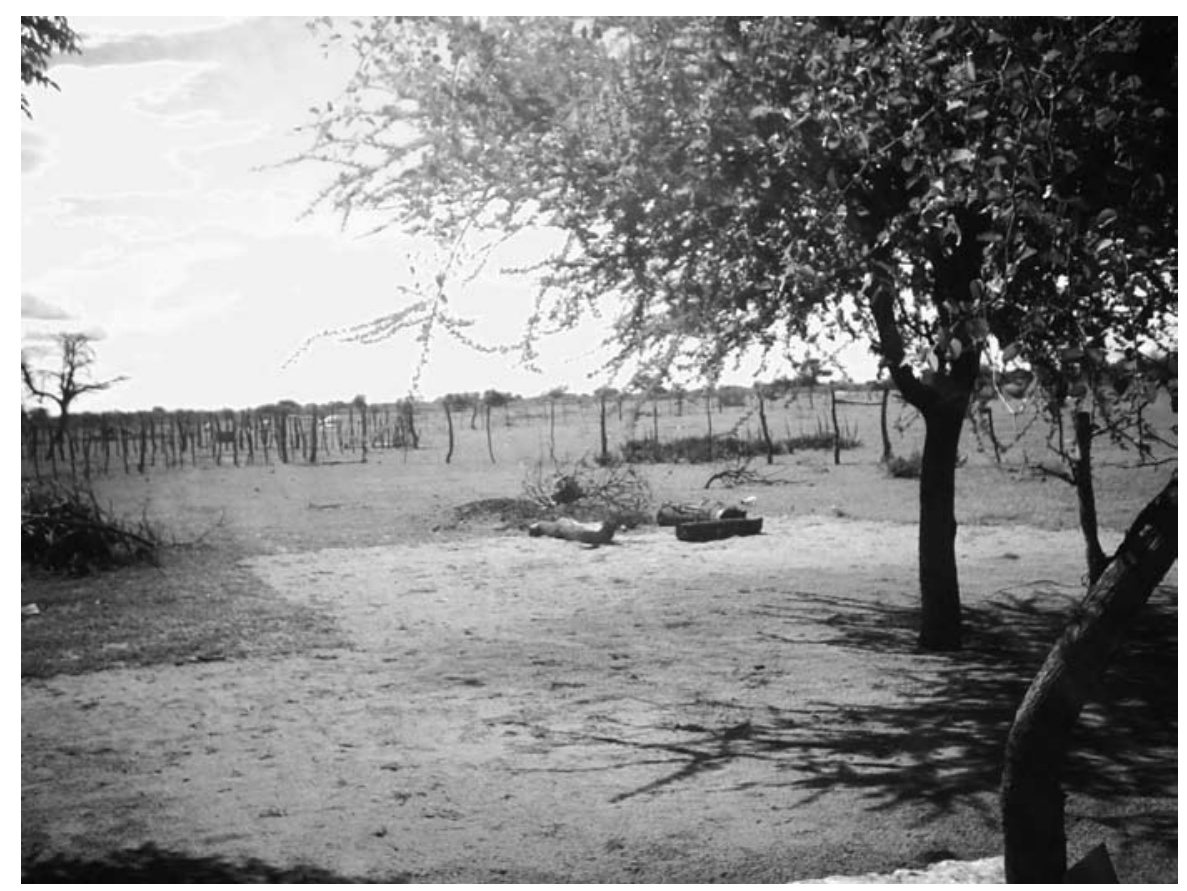

O Fogo Sagrado - Foto: Josué Tomasini Castro causando o infortúnio. O morto 
Ihe dirá qual é o problema - se o filho pecou em algum de seus "tributos de submissão" (Vansina 1962) ou se ele foi enfeitiçado -, ao que o velho deverá então sacrificar algum animal ou borrifar ritualmente água no infortunado (como uma "lavagem"), trazendo-o diante do Fogo Sagrado e aplacando assim as forças que o castigavam.É responsabilidade do homem observar as restrições alimentares e sociais - quando necessárias - e apenas ele pode e deve conversar com os ancestrais. Sua família apenas o auxilia quando ele não está em casa - já que os ancestrais exigem que as brasas de dentro da casa sejam levadas ao Fogo Sagrado diariamente e, "caso isso não ocorra [algumas pessoas afirmavam], as pessoas começam a desaparecer e os ancestrais não aparecem mais". A única coisa que a família do velho pode fazer é levar as brasas de dentro da casa até o Fogo Sagrado - desde que a pessoa que fizer isso esteja saudável.

Em um sentido cosmológico (por mais que se tenha mais racionalização - conhecimento - do que fé crença), reconhece-se a existência de um deus supremo, ndjambi, que teria sido o criador do universo, mas que, após criar o mundo, retirou-se para longe dos homens e lá permanece, sem interesse pelos homens e seus feitos e também sem despertar o interesse da sua criação em conhecê-lo melhor.

Como é comum em boa parte do continente - principalmente nas regiões bantu, nas áreas culturais que Herskovits $(1924,1962)$ chamou de Área do Congo e Área de Gado da África Oriental (nas quais se encontram, entre outros, os Azande, Bakong, Kongo, Shongo, Lunda, Lele, Bushongo, além dos pastoris Nuer, Zulu, Ngoni, Logoli, Ngwato, Masai e Nandi) -, ao comentarem a existência de Ndjambi (ou Nzambe), as pessoas simplesmente dirão "sim, sim, o conhecemos, mas não sabemos muito sobre isso"; em geral, não há interesse em saber mais, e tal foi o que percebi durante minha pesquisa.

Além de Ndjambi, reconhece-se a história de Mukuro, o primeiro herero. Também conhecido como “o velho", acredita-se ter sido criado junto com Kamungarunga, a primeira mulher herero, e da mesma árvore que as vacas - que têm um papel muito importante no Fogo Sagrado, justamente porque são os símbolos de riqueza, autoridade e poder de toda uma família. Ele pode ser entendido como o grande antepassado, o velho que pleiteia as necessidades dos seus herdeiros a deus, sendo também reconhecido como uma divindade, um ser dotado de poderes dados pelo próprio Ndjambi, seu criador. No entanto, tal como o primeiro, sua imagem não é utilizada na prática do Fogo Sagrado.

Tem-se, assim, um deus supremo (Ndjambi) que, como o deus cristão, é considerado o criador de todas as coisas. Foi ele quem deu o fogo aos primeiros herero; foi para não esquecê-lo que "o fogo foi guardado"; e foi ainda ao perceber que esse deus não era um ser tão próximo assim que os ancestrais, os "velhos" (hokuru), teriam ressurgido. Alguns de meus interlocutores diziam, inclusive, que antes de o Fogo Sagrado existir nas suas formas atuais ele era simplesmente o local onde os homens se sentavam sozinhos para transmitir aos mais novos seus conhecimentos. Assim, como o lugar onde pais e filhos se encontravam em privacidade, o atual Fogo Sagrado não mudou muito. As relações, como já comentei anteriormente (notas 2 e 7), dão-se em um plano secular e não sagrado.

Esta é a base do conhecimento do Fogo Sagrado, tradição que possui seres sobrenaturais mas que, na prática, ou seja, como forma de perceber e agir sobre o mundo, está firmada sob a égide da senioridade, sendo esta o princípio organizacional do mundo visível e das regióes invisíveis, e seus elders já mortos (os "ancestrais") e o local de seus encontros (o "Fogo Sagrado" em si) os principais elementos referenciais deste complexo. Podemos agora, com mais propriedade, entender os processos que aqui serão descritos. 
O sol estava começando a se pôr, as cabanas ${ }^{18}$ começavam a fechar - a comida já havia acabado - e eu retornava para meu quarto, uma barraca alocada em um pequeno aposento sem piso junto ao terreno da igreja Missão Arrependam-se da Namíbia. O dia havia sido divertido, passara a maior parte dele com Clerence e Kambila conversando sobre diferentes assuntos, andando por todo vilarejo.

Eu já havia me despedido deles, estava a alguns metros do meu local de hospedagem, quando um senhor de mais ou menos cinqüenta anos de idade gritou: "Indjo"19. Ele me chamava para uma breve conversa. Este homem, Caspa - que mais tarde descobri ser o diretor da Escola Júnior Secundária de Okondjatu e presbítero da igreja Oruuano -, e mais dois amigos seus que estavam escorados em um carro queriam saber o que eu estava fazendo em Okondjatu. Ele afirmava já ter me visto andando pelo vilarejo, mas como é um homem muito ocupado não tinha conseguido conversar comigo ainda.

Fui questionado sobre o porquê de estar ali já há algum tempo e sobre qual era o meu interesse na localidade. Aproveitei o momento para fazer mais alguns contatos e deixar claro que não havia qualquer vínculo meu com o local onde eu estava morando - o terreno de uma igreja - (ou seja, eu não era nenhum pastor, missionário ou evangelista) e que eu estava lá para estudar melhor algumas questões relacionadas com a cultura e a religião herero. Ao ser perguntado sobre como estava minha pesquisa, disse que tudo ia se encaminhando tranqüilamente e comentei brevemente que eu havia ido até a igreja da Estrela de São Josué para assistir a um culto na noite anterior, mas que o bispo havia cancelado o culto. Comentário completamente despretensioso, apenas para demonstrar meu interesse e me afastar de qualquer conexão com a igreja onde eu estava hospedado.

Ao ouvir isto Caspa comentou, com um certo desconforto, que isso acontecia regularmente e que ele mesmo ia à igreja algumas vezes e, sozinho, orava e lia a Bíblia enquanto esperava por aqueles que deveriam estar lá, mas não estavam. Após esse comentário, ele aponta para seus dois amigos e afirma: "esses dois mesmo, eles deveriam ir e não vão há muito tempo". Os dois homens baixam a cabeça - mas sem muito constrangimento enquanto Caspa continua: "todos deveriam ir lá, são todos nossos membros, [...] nós somos a igreja tradicional herero" (12.01.2006, Namíbia).

Nossa conversa foi rápida, talvez quinze minutos apenas, mas esses poucos minutos me deixaram pensando a noite toda. O que significa afirmar ser a igreja cristã tradicionalmente herero? Até então, a palavra tradição nunca havia sido usada nesse sentido "cristão", ao contrário, os moradores deste vilarejo a usavam como referência ao complexo da ancestralidade, para caracterizar o, este sim, "tradicional" Fogo Sagrado ${ }^{21 .}$

Esta é a frase que despertou minha curiosidade para a elaboração deste ensaio e conduz agora a um esboço histórico sobre a formação dessa igreja para elucidar melhor essa questão, permitindo que o texto vá além do simples registro de uma situação etnográfica, adentrando, para aludir a Hans-Georg Gadamer (1975), uma certa hermenêutica que, ao fim, sob certos aspectos teóricos, deverá ajudar a compreender a perspectiva do presente na qual esta igreja e o pesquisador se encontram. 
A igreja Oruuano é uma dissidência dos herero com os trabalhos da Sociedade Missionária Rhenish, uma das maiores sociedades missionárias da Alemanha de base luterana. Amálgama de várias pequenas missões, a Sociedade foi criada oficialmente no ano de 1828 e já ao fim do mesmo ano havia ordenado os primeiros missionários e os enviados ao sul da África.

Logo no início dos trabalhos, os missionários começaram a migrar para o norte, em direção ao sudoeste africano. Neste trajeto, deram-se os primeiros contatos entre a Missão e os herero, contato este que viria a continuar por um longo tempo. Desde os primeiros anos, a relação entre a Sociedade e os grupos locais foi uma relação mediada por ações políticas; tal como as demais sociedades missionárias em relação a outros grupos, esta usava seu domínio colonial - e mesmo armamentista - para controlar e fazer guerras ${ }^{26}$.

Nos anos que antecederam aquele que seria o maior conflito entre hereros e alemães, a Sociedade Missionária Rhenish estava em próxima relação com Samuel Maharero o qual, apoiado pelos missionários e pelos próprios alemães, ajudou as forças coloniais a matar Maharero, seu pai e um dos grandes chefes herero. Samuel havia feito um acordo com as autoridades coloniais para que, com a morte do seu pai e sua nomeação como chefe herero, parte da terra fosse dada aos alemães em troca de armas, roupas, alimentos, bebidas etc., os quais, acreditava Samuel, iriam ajudar sua comunidade. Mas ele não herdou as possessões de seu pai e as promessas feitas pelos alemães tampouco foram cumpridas, o que acabou por contribuir para a ramificação dos herero - que começavam a se dividir ainda mais sob a liderança de diferentes chefes - e para aumentar o domínio dos colonos sobre as terras nativas.

Este foi um dos fortes argumentos que acabaram levando Samuel Maharero a travar a sua mais dura guerra contra as forças coloniais. Conjugado a outras questões oriundas de um contato problemático e de intermináveis pequenos conflitos entre colonizadores - alemães - e colonizados - hereros -, em 1904 tem início a guerra que levou à morte mais de $70 \%$ da população nativa ${ }^{27}$.

No período do conflito com os alemães, os missionários Rhenish controlavam "15 estações missionárias, 32 estações avançadas, e 48 escolas missionárias com 1.985 alunos e 7.508 fiéis" (Dierks 2002:96), o que se caracterizava como a maior infiltração missionária naquela região da África. Durante os anos de 1904-1906, estes locais servirão de prisão para aproximadamente 12.500 herero - a maioria mulheres e crianças.

Passados estes anos de guerra e após o desmantelamento das estruturas sociais herero, estes começam a reorganizar-se, de forma inovadora, como uma "nação" ${ }^{28}$. Sob a liderança de alguns de seus evangelistas e seguindo os ensinamentos do cristianismo luterano, os herero iniciam um ainda pouco significativo movimento nacionalista - já que grande parte do grupo estava ainda disperso pelos países vizinhos e muitos dos seus líderes estavam mortos. O movimento, no entanto, aos poucos ganha força com a liderança de Hosea Kutako - “conhecido como o pai do nacionalismo moderno namibiense" (Dierks 2002:203) -, que teria um papel muito importante na criação da igreja Oruuano e na organização dos herero enquanto uma nação.

Um aspecto interessante nestes movimentos iniciais é a forma como as novas conversões se distinguem das anteriores a 1903. "Os herero convertidos antes de 1903 tinham aceitado o conceito moral missionário da Sociedade Missionária Rhenish. Os herero convertidos no período entre 1904 a 1914 mantêm o paradigma das estruturas de liderança tradicional existentes antes da guerra" (Dierks 2002:147). Assim, assume-se que nos 
períodos imediatos ao pós-guerra, todas as reivindicações feitas anteriormente começaram a tomar formas mais objetivas, a ser reconhecidas e percebidas pelas forças dominantes.

No início da década de 1920, com uma certa liberdade momentânea permitida pelo governo sul-africano - que, com o fim da Primeira Guerra Mundial, anexou o território alemão à colônia inglesa - o movimento se fortalece ainda mais (cf. Dreyer 2004). No dia primeiro de setembro de 1920 uma carta é submetida ao então primeiroministro sul-africano Jan Christian Smuts em nome dos herero pedindo que os missionários alemães fossem removidos do território, pois eles haviam-nos traído durante o período da guerra de 1904-1906 e continuavam a fazê-lo. O pedido foi aceito, porém três anos mais tarde os primeiros missionários alemães começavam a voltar ao território.

Menos de um ano depois, em abril de 1921, Eduard Kriele, inspetor da Sociedade Missionária Rhenish, confirma tais fortalecimentos nacionalistas ao perceber o fenômeno de uma crescente "obsessão por liberdade misturada com um espírito de não-arrependimento" (Dierks 2002:176). Tais reivindicações, vistas do ponto de vista herero, seriam uma tentativa de recuperar o que havia sido perdido durante os primeiros períodos da situação colonial e de se livrar das prisões salvacionistas dos missionários europeus, possibilitando-lhes aproximar-se novamente de seus antigos costumes - a igreja Oruuano foi também resultado destas motivações.

Ainda outro evento marcou este momento e foi responsável por agravar as já complicadas relações entre os missionários Rhenish e os herero. No dia 23 de agosto de 1923, ocorreu em Okahandja o enterro de Samuel Maharero - no mesmo local onde seu pai, seu avô e outros heróis herero foram enterrados -, um símbolo do orgulho herero recuperado, já que Samuel morreu exilado em Bachuanaland e, portanto, trazê-lo de volta a Okahandja, principal assentamento herero, era um gesto de desafio às autoridades e reforço nacionalista herero.

Seguido de um culto liderado pelo missionário rhenish Heinrich Vedder, o funeral ocorre no pátio da igreja, liderado por Hosea Kutako e de acordo com o costume herero. Inevitavelmente o acontecimento acaba por aumentar a crise com a Missão Rhenish, já que esta ainda mantinha sua visão de "civilização cristã ocidental" e uma interpretação pietista do cristianismo, o que impossibilitava qualquer tolerância por parte dos missionários a respeito do ocorrido.

Além deste, outros acontecimentos foram somados àqueles, contribuindo igualmente para o crescimento dos movimentos nacionalistas e para a organização dos herero. Um ponto importante nesse processo foi o início dos trabalhos do Conselho dos Chefes herero em 1945. Criado por Hosea Kutako em cooperação com o filho de Samuel Maharero, Frederick Maharero, o conselho foi responsável por uma maior legitimidade herero enquanto nação, conjugando esforços dos diferentes líderes contra o domínio europeu.

Conjuntamente ao aumento dos movimentos nativos, outro elemento que contribuiu para que os valores da minoria nativa pudessem ser objetivados, percebidos e entendidos por todos foi o enfraquecimento da Sociedade Missionária Rhenish. Como resultado das crescentes críticas de seus adeptos africanos às atitudes colonialistas de seus missionários, a Sociedade começa a perder forças, tendo algumas de suas congregações entre os herero sido desvinculadas da missão por seus líderes nativos.

O elemento final a compor este quadro que, acredito, culminou na criação da igreja Oruuano, foram os discursos dos missionários a respeito do apartheid. Em 1950, o ex-missionário rhenish Heinrich Vedder - o mesmo que presidiu o culto no funeral de Samuel Maharero - aceita o cargo de senador no Senado Sul-Africano, sendo responsável pelo "Departamento das Questões Nativas". Em seu primeiro discurso oficial, ele comenta a 
respeito daquela questão, afirmando: “Nosso governo na África do Sudoeste recebeu uma ótima herança. Desde o início do governo alemão temos realizado aquilo que infelizmente ainda não foi efetuado na África do Sul, tal seja: o Apartheid" (cf. Dierks 2002:211).

No mesmo sentido, e minando ainda mais o domínio da Missão Rhenish, foi realizada em Windhoek, algumas semanas depois das declarações de Vedder, a Conferência Missionária Rhenish, na qual o apartheid foi o principal tópico, sendo entendido por grande parte dos conferencistas como um movimento positivo que, acreditavam eles, promovia "o desenvolvimento separado dos nativos de acordo com suas distintas características" (id.).

Pouco mais de um mês após essa conferência, Hosea Kutako se encontra em Windhoek com Preses Diehl, da Sociedade Missionária Rhenish, esperando traçar alguns objetivos conjuntos que poderiam mudar o futuro da sua comunidade e, de fato, de muitos namibienses. No entanto, a declaração feita por Kutako - de que conforme a concepção herero a igreja, como igreja nacional, não poderia existir sem incluir os direitos do povo onde se encontra - não foi suficiente. A Missão Rhenish manteve o discurso de que o trabalho missionário teria que acabar caso confundisse questões mundanas com espirituais.

Assim, apesar de algumas outras frustradas tentativas de unir as Missões Rhenish sob uma única igreja, para tentar impedir o fortalecimento das congregações nativas, no dia 25 de agosto de 1955 os herero assumidamente deixam a Missão Rhenish e criam o Movimento Oruuano ${ }^{29}$ sob a liderança de Reinhard Ruzo, ordenado em 1949 pela Missão Rhenish. Ao lado de Ruzo, Hosea Kutako e outros chefes herero cumprem um papel central na formação da "igreja anti-apartheid", como ela também era conhecida.

Nasce, enfim, a igreja Oruuano - objetivação reforçada das demandas por terra, liberdade e "autoidentificação" pelos herero, pela minoria -, vista pelos missionários como mais um setor aquecido pela onda de nacionalismos na Namíbia, um movimento "confuso e que prega falsas doutrinas", um "despertar nacionalista (...) que trouxe um certo reavivamento da velha adoração aos ancestrais" (Dierks 2002:216). É a religião do branco, do colono, "revisada, transformada, e apropriada (...) para enfraquecer seu poder dentro do universo de discurso [dos nativos]" (Apter 2005:178), para reforçar os sistemas nativos de fé e política, para reforçar uma identidade.

As fronteiras, que antes eram controladas por homens armados nas trincheiras coloniais, foram ultrapassadas. Ao reivindicar uma igreja cristã herero, aqueles homens tomam posse daquilo que os controlava; procuram se elevar a um status que antes não lhes era possível possuir. Nessa absorção ${ }^{30}$ de novos territórios, a fronteira religiosa de seus fiéis se alarga, mantendo em seus repertórios tanto a crença no Fogo Sagrado como nas doutrinas cristãs, fortalecendo a identidade do grupo que agora se apropria dos elementos que antes o constrangiam.

\section{O PRESENTE: A IGREJA ORUUANO EM OKONDJATU}

Talvez agora, após essas observações, seja possível imaginar o porquê de esta igreja ser considerada por muitos como a "igreja tradicional herero". Sem muitas dificuldades seria ressaltado que isto ocorre pelo fato de ela ter sido um dos resultados de um amplo movimento de luta a favor da tradição herero e da restituição de suas posses perdidas durante o colonialismo. Assim, seguindo ainda na hermenêutica de Gadamer (1975), faz-se necessário 
voltar agora dessa perspectiva histórica ao presente, pensando mais criticamente a situação atual na qual esta pesquisa está inserida.

Ao realizar tal movimento, parece inevitável questionar o que uma frase como aquela - "Nós somos a igreja tradicional herero!" - pode significar em um local como Okondjatu. Dizer-se tradicionalmente herero, em um local onde a distinguida "tradição do Fogo Sagrado" não possui raízes muito profundas, pode ter um significado sincrético de poder ainda um pouco mais elaborado.

Nesse sentido, afirmar-se como um "cristão tradicionalmente herero" em meio a um povo que tem orgulho de seu passado e de suas tradições (por mais que o Fogo Sagrado não seja um elemento muito presente na vida de grande parte dos moradores de Okondjatu, a maioria deles respeita sua tradição, vendo-a, por vezes, como um presente do próprio deus) é um esforço para obter maior controle sobre um certo estoque de significados. Afinal, eles não só vão à igreja, como também vão ao Fogo Sagrado; eles não só pedem a Jesus, como pedem também aos ancestrais.

Afastando todos aqueles movimentos nacionalistas do passado, os quais não necessitam mais ser tão elaborados, deve-se poder perceber que os significados de discursos estruturalmente semelhantes - como o de se afirmar a igreja tradicional herero - modificaram-se ao longo do tempo. Não há mais necessidade de pregar a criação de uma forte igreja herero. $\mathrm{O}$ inimigo colonialista a ser combatido já foi derrotado - restam, talvez, apenas as armaduras, as armas e o sangue -, o território agora é de livre competição entre diferentes sistemas religiosos e não de imposições forçadas de um grupo dominador a um outro dominado.

Ora, se apelar para um passado heróico não causa mais o mesmo efeito - e em Okondjatu a ineficiência destes apelos pode ser verificada no fraco interesse da população na igreja Oruuano (comentarei esta questão ao final deste ensaio) -, novas estratégias devem ser traçadas com o fim de desviar-se deste novo obstáculo, tal seja: a competição e não mais a imposição de diferentes repertórios religiosos. É quase um processo de qualificação, pois à medida em que a competição pelo mercado religioso aumenta, novos elementos devem ser alçados para se obter adeptos: se certa estratégia que vinha funcionando anteriormente já não funciona mais, algumas alterações devem ser feitas.

Em Okondjatu, no discurso de Caspa, essa estratégia foi tomar um importante tópico existente entre os herero - qual seja: o Fogo Sagrado e outros símbolos da "tradição" herero - e colocá-lo como elemento relevante dentro deste complexo para, assim, poder afirmar com todas as palavras e em oposição a outros sistemas religiosos: "nós não somos contra o Fogo Sagrado porque nós nascemos com ele" (12.02.2006, Namíbia).

Esse parece ser o maior objetivo de se colocar como pertencente à igreja tradicionalmente herero: afirmar-se defensor de uma tradição há muito combatida. Isto, para as atuais populações herero, é uma questão de orgulho, tanto pelos feitos do passado como pelas suas tradições, que continuam sendo combatidas por alguns outros tipos de conhecimentos religiosos - declaradamente, por estar em uma situação religiosa plural; a igreja é condenada, mas também condena.

Analisando ainda um pouco mais esta mesma frase, e pensando na posição do próprio pesquisador diante da situação, pode-se supor que Caspa procura relacionar dois sistemas religiosos em um único quadro não apenas com o intento de convocar os seus próprios compatriotas, mas também de se mostrar legítimo diante de um homem, branco, que à primeira vista e sem muita dificuldade poderia ser denominado cristão.

Talvez aqui já seja possível perceber os sincretismos, aquela tendência em ressemantizar seu próprio 
universo com relações apreendidas no mundo do "outro" para fortalecer o seu próprio discurso. No caso da igreja Oruuano é possível pensarmos em um perspectivismo que faz, ora do cristianismo, ora do fogo sagrado, o "outro" do qual apreendem-se relações, sendo que os sujeitos se mantêm de forma negociada no interstício dessas relações - e, de fato, a igreja Oruuano parece estar localizada junto a estes espaços.

\section{Cristianismo e Fogo Sagrado: tentativas de reconciliação}

Uma análise mais focada no quadro específico da igreja Oruuano poderá auxiliar no entendimento de como estas conciliações ocorrem com vistas a acabar com quaisquer supostas dicotomias e alegações de sincretismo, sendo que este último é contundentemente negado e combatido - o que vem a ser outro ponto interessante para o estudo em questão.

Tem-se, assim, dois sistemas lógicos, usados para dar uma base suficientemente firme para que a afirmação discutida anteriormente pudesse ser formulada. Os dois teriam como objetivo acabar com o conflito entre as concepções cristãs e o Fogo Sagrado. O primeiro, de aparência anti-sincrética, buscando fornecer algumas modificações estruturais, tentará reforçar o próprio cristianismo e afastar, dessa forma, possíveis contradições; o segundo, a partir de um processo de reinterpretação das crenças "nativas" pelas lentes das concepções cristãs, procurará reforçar a tradição herero.

\section{(a) Reforço do cristianismo}

Em uma das conversas que tive com Caspa, alguns dias após aquela intrigante definição da sua igreja, comentávamos a respeito do valor do Fogo Sagrado para a igreja Oruuano e de como esta questão foi importante no combate ao controle hegemônico das forças colonialistas. Nesta discussão aparecem as primeiras articulações em vias de acabar com qualquer possível dicotomia na existência mútua do cristianismo e dos ancestrais em um mesmo quadro.

É necessário legitimar o uso destes dois sistemas distintos em um mesmo conhecimento religioso, já que por ambos os lados há a exigência de uma certa exclusividade. Zorowa (ela mesma convertida ao cristianismo), uma senhora de 89 anos, lembraria que os ancestrais já não são mais os mesmos. Com a chegada dos missionários ao território, Zorowa continua, este sistema se fragmentou e foi posto em um mercado religioso junto com outras crenças e deuses sem maiores implicações para aqueles que daquele momento em diante o rejeitaram. Mesmo tendo a Bíblia, Jesus e lahweh já perdido seu sistema legitimador tal como ocorria na Europa, as críticas elaboradas pelos missionários continuavam, pois, sabe-se, o caminho proposto por estes é um de dimensões bem restritas e, entre elas, o (que para eles era um) "culto aos mortos" é um ponto amplamente combatido desde o antigo testamento. Assim, seria preciso elaborar algumas modificações que permitissem o uso conjugado destes dois sistemas (aparentemente contraditórios) em um único universo religioso.

A estratégia, para Caspa, foi a de elaborar algumas distinções entre a igreja e o Fogo Sagrado, entre religião e cultura. Tomando a mesma direção do Concílio Vaticano $\|^{31}$, Caspa defende uma cisão entre o conhecimento religioso e os costumes culturais. Assim, transformando discursivamente algumas relações estruturais, ele pode afirmar: 
“Nós não somos contra o Fogo Sagrado, sabe, ele é como um presente, todas as nações têm seus presentes e isso é natural. É como eu e você, nós comemos coisas que você não come, que você não sabe e isso não é errado. Mesmo o pastor da nossa congregação tem seu próprio Fogo Sagrado. Aos domingos pela manhã, ele vai acordar no nascer do sol, vai se sentar lá [diante do Fogo Sagrado] e fará as coisas culturais, depois ele vai pegar sua Bíblia e virá pregar na igreja" (01.02.2006, Namíbia).

Muito interessante esta separação que ele tece entre as coisas culturais e as coisas - agora digo eu - religiosas, separando a relação com os ancestrais do quadro da igreja Oruuano. Talvez Caspa pudesse dizer, como disseram alguns missionários Rhenish, que não seria bom misturar questões mundanas com questões espirituais. Uma coisa é ir à igreja, outra coisa é ir ao Fogo Sagrado, não há contradição nisso. Religião e cultura estão dispostas em diferentes quadros no conhecimento religioso da igreja Oruuano.

Ao analisar alguns outros comentários a respeito das doutrinas dessa comunidade religiosa, percebe-se que, no quadro geral da igreja, este sistema aparentemente funciona exatamente da forma como foi prescrito pelos missionários. Por isso, o Fogo Sagrado e os ancestrais não são invocados na igreja, dentro do quadro Oruuano. Ao comentar sobre os processos de cura - de muita procura em Okondjatu e na Namíbia em geral -, Caspa parece confirmar ainda mais suas afirmações anteriores, ao afirmar:

“Na nossa igreja, se você diz que está com AIDS, nós iremos apenas orar por você, não temos nada para dar para você beber ou o que seja, seremos apenas eu e você orando pela cura, nós não temos todas aquelas coisas [como outros conhecimentos mágico-religiosos] de fazer isso e aquilo [...] depois de orar, você poderá ir ao Fogo Sagrado, mas isso não tem nada a ver com a igreja" (01.02.2006, Namíbia).

Certo é, no entanto, que mesmo estruturalmente dispostos em quadros diferentes, tanto igreja como Fogo Sagrado são elementos presentes dentro do repertório dos fiéis desta congregação e, por isso, não se anulam. Eles funcionam como oportunidades plurais de acesso aos bens sagrados, o que torna ainda mais difícil entender a lógica defendida por Caspa. É como se houvesse um link dentro do quadro religioso que permitiria ao indivíduo se reportar religiosamente ao aparato cultural sem, no entanto, negar seu aparato religioso.

Esta divisão está de acordo com meus comentários anteriores de que o Fogo Sagrado seja despido de seus contornos religiosos (e falo da noção ocidental do termo): ele é secular (cultural, nas palavras de Caspa) e não sagrado. Esta divisão é muito bem-vinda para Caspa, pois ela o ajuda a reforçar o cristianismo dentro da lógica Oruuano, permitindo que ambos os sistemas existam dentro de um mesmo dogma, sem serem contraditórios.

No entanto, ao procurar reforçar a tradição herero em relação ao cristianismo, Caspa parece igualar o Fogo Sagrado ao religioso. Mais um dos produtos das relações coloniais, o Fogo Sagrado pode assumir, em certos momentos, um papel religioso, numa tentativa de terminar com as afirmações cristãs de que a cultura herero representada pelo dito "culto aos ancestrais" era diabólica e, por isso, encontrava-se em uma situação de inferioridade em relação ao mundo cristão/ocidental. 
Em aparente oposição às definições anteriores, Caspa parece trazer o Fogo Sagrado mais uma vez para dentro do quadro de seu conhecimento religioso, tecendo algumas outras articulações com vistas a garantir também a legitimidade do Fogo Sagrado e da sua cultura, criando arranjos que os expliquem a partir dos discursos religiosos.

Assim, religião e cultura, antes quadros opostos um ao outro, agora formam um sistema corroborador, onde ambos se justificam, sendo este o momento mais visível do encontro entre o Fogo Sagrado e os ideais cristãos da igreja Oruuano:

“Mas, se você voltar na Bíblia, os israelitas tinham um altar. O altar é como o Fogo Sagrado, sabe, aquilo é o tipo de crença dos herero... E nós acreditamos nele porque é o nosso presente, é aonde os mais velhos vão para falar com os ancestrais, para que estes falem com deus e peçam chuva... Eles pedem ajuda para deus, assim como os israelitas faziam quando chamavam Abraão, Jacó e Isaac" (12.02.2006, Namíbia).

Logo, para Caspa, a relação com os ancestrais e conseqüentemente a existência do Fogo Sagrado não poderiam ser combatidas nem mesmo pelos cristãos mais fervorosos, afinal, tais preceitos são também bíblicos. $O$ altar dos israelitas, onde os sacrifícios eram feitos e a presença de deus se manifestava, muito se aproxima do Fogo Sagrado que (tal como é chamado ainda em alguns grupos herero) por muito tempo era também conhecido como o "local dos sacrifícios"32. Para aproximar ainda mais a relação entre vivos e mortos do conhecimento cristão luterano (que não admite o culto a outros deuses), pode-se trocar a concepção missionária (e muitas vezes antropológica) de "culto aos ancestrais" pela de "petição aos ancestrais". Dessa forma, Caspa afirma:

“Nós não podemos dizer que nós oramos àquelas pessoas, aos ancestrais, nós não os cultuamos, apenas pedimos a eles para que eles peçam para deus nos ajudar [...] Como disse, funciona da mesma forma com os israelitas. Por que eles estão chamando a Abraão senão justamente para que este leve seus pedidos direto a deus?" (12.02.2006, Namíbia).

Assim, para Caspa, não há nada de contraditório entre o uso do Fogo Sagrado e a crença na Bíblia e na religião cristã. Diferentemente de alguns outros cristãos, a Bíblia, para Caspa, serve para corroborar o Fogo Sagrado e não para negá-lo, dando um pano profano a algo que deveria ser evitado. Neste sentido, o antes afastado quadro da tradição herero agora se aproxima ao ser justificado pelo aparato religioso cristão. 


\section{Os sujeitos sincréticos}

Feitas essas distinções se torna difícil visualizar onde, exatamente, encontram-se as incursões sincréticas; em que momento pode-se perceber dois elementos de diferentes sistemas religiosos interagindo em um único quadro. Se estruturalmente os arranjos favorecem a distinção - entre cristianismo e Fogo Sagrado -, na prática, fazendo uma análise dos diferentes quadros em questão - religião e cultura -, a própria estrutura da igreja Oruuano abrange essas distinções.

Afirmar que a relação com os mortos é cultural e não religiosa é uma estratégia para legitimar o que, antes da "tomada do poder", era ilegítimo. Por isso, neste caso, o sincretismo entendido como estratégia de poder e redefinição de identidades está vinculado àqueles que, sincreticamente motivados, traçam re-elaborações de dois sistemas religiosos distintos, de forma a abrigá-los em um único complexo de conhecimento religioso, eclesiasticamente cristão, mas tradicionalmente herero - daí a frase: "nós somos a igreja tradicional herero!".

Nesse sentido, parece mais correto afirmar que sincréticos são os indivíduos que se apropriam de diferentes discursos para corroborar suas próprias construções de fé. Não há sincretismos quando o pastor da igreja Oruuano acorda pela manhã e se dirige ao seu Fogo Sagrado onde fala com seus ancestrais; assim como não há sincretismos quando o mesmo toma sua Bíblia e vai à igreja pregar a "palavra de deus". Os diferentes sistemas não foram "infectados", nem mesmo "corrompidos", continuam existindo da forma prescrita sem misturar elementos exteriores.

É o próprio sujeito, ao que parece, que traça sincretismos ao justificar sua crença, ao abrigar em si dois sistemas de contato com o invisível - um a partir da religião e outro a partir da cultura -, mas não ao vivenciá-los; pois, ao fazê-lo, ele estará apenas tomando proveito de uma situação plural, acrescentando elementos em seu próprio repertório. Assim, os sincretismos presentes na igreja Oruuano existem como justificativas individuais de re-apropriação de uma identidade antes combatida - a dos hereros e seus ancestrais.

Dessa forma, o sincretismo é então entendido como um catalisador de identidades. Ou seja, é justamente a partir de estratégias sincréticas que os indivíduos dão novos sentidos e significados à nova realidade que agora os cerca e elaboram formas de manter suas identidades mesmo diante da constante negação das mesmas. Assim, o sincretismo constrói e mantém as (novas) identidades, ao invés de eliminá-las. 
O sincretismo, entendido como um instrumento estratégico de resistência, tem suas origens desde Plutarco (AD 45-125). Shaw e Stewart lembram as palavras de Kenneth George, para quem a própria história do termo cunhada pelo filósofo grego - segundo a qual sincretismo seria a junção estratégica de diferentes grupos cretenses que, por um momento, deixavam suas desavenças de lado para lutar contra inimigos estrangeiros - deveria lembrar que "a arena do sincretismo é um local de diferença, contato e reconciliação profundamente politizada" (Shaw \& Stewart 2005: 155).

O uso de sincretismos como estratégias de sobrevivência cultural há algum tempo já vem sendo descartado e rigidamente contrariado. A idéia evolucionista, defendida por Nina Rodrigues, do sincretismo afro-brasileiro como uma "ilusão de catequese", e a idéia funcionalista que o entende como uma "máscara colonial para escapar à dominação" (Ferretti 1995:88), vêm sendo duramente criticadas por alguns estudiosos.

Fato é, no entanto, que em situações em que duas culturas diferentes - duas tradições ideológicas, dois povos, duas religiões, dois sistemas econômicos etc. - mantiveram um prolongado contato uma com a outra, geralmente se percebem certas restrições de um sistema ao outro, certas imposições, alguns "controles de estoque" e defesa de algumas fronteiras, o que acaba por hierarquizar certas posições de poder e domínio. Em geral essas definições, quando em tempos coloniais, como ressaltam Berger e Luckmann, seriam determinadas "por aqueles que empunhavam as melhores armas e não por aqueles que possuíam o melhor argumento" (Berger \& Luckmann 1983:148); hoje, os embates e estratégias se apresentam justamente como forças argumentativas.

Essas imposições de um sistema ao outro se dão pelo fato de que, como as religiões, as culturas também tendem a lograr um status de verdadeiras - as únicas verdadeiras, vale dizer. Tais julgamentos de valor - isto é verdadeiro, isto é falso, isto é divino, isto é demoníaco etc. - acarretarão a definição de uma cultura padrão, de uma atitude a ser copiada, na tentativa de legitimar uma tradição autêntica em relação a uma tradição que deve ser "convertida".

O ocorrido entre os herero e entre tantos outros povos africanos, latino-americanos, asiáticos etc. é um exemplo disso. Da mesma forma, as reações sociais oriundas daquelas imposições, visando garantir a continuidade de certos costumes (agora reelaborados talvez), podem também ser percebidas entre diversas sociedades.

Ainda um ponto interessante a se pensar é o fato de que mesmo com o fim dos períodos "oficialmente coloniais" há ainda certos confrontos, certas imposições de modos de ver o mundo sobre outros. Tal como visto neste trabalho, os desdobramentos históricos mudam também a relação entre os atores (ou seja, as formas distintas de confronto no passado e no presente da história herero, por exemplo), bem como os focos de resistência. Os atores são outros (não necessariamente novos, podem ser os mesmos transformados pelo tempo, neste caso, os herero e o cristianismo - europeu), mas a afirmação de uma identidade sócio-cultural persiste.

Anteriormente no texto comentei o fato de que a igreja Oruuano já não possui um rol de adeptos muito grande. Aquilo que lhe garantia a existência (a luta anti-colonial) não é mais um discurso válido para as realidades atuais. Apesar de a igreja ser ainda reconhecida como a "igreja tradicional herero" as pessoas, hoje, lançam mão de outros instrumentos para resolver seus problemas do agora.

Em agosto de 2008, tive a oportunidade de voltar à Namíbia para outra breve incursão a campo e ao visitar Okondjatu tal foi minha surpresa ao perceber que, pouco mais de dois anos depois de minha primeira experiência 
de pesquisa, o templo da igreja Oruuano neste vilarejo estava com suas portas permanentemente fechadas já há mais de um ano, enquanto as outras igrejas lá presentes viram seu número de fiéis aumentar. Infelizmente não tive a possibilidade de conversar com Caspa novamente, mas parece que todo o esforço de se inserir no mercado religioso contemporâneo não funcionou, pelo menos não em Okondjatu.

Minha última ida a campo se deu com o intuito de me aproximar de outro projeto identitário herero: as comemorações anuais em Okahandja, quando muitos hereros se reúnem para, entre outras coisas, prestar reverência aos seus grandes chefes enterrados nesta cidade e fazer reivindicações por reparações históricas aos alemães pelos conflitos do passado. $O$ evento ocorre em um descampado na periferia, onde está o commando de Okahandja (como que um quartel general). Logo ao se adentrar o commando lá está posto o Fogo Sagrado do rei Maharero, Alfons. Ele trouxe as brasas de sua casa e as acendeu lá. Durante todo o evento, as pessoas que chegam ao commando vão até o Fogo Sagrado prestar reverência ao rei e aos seus ancestrais. No último dia do evento, após a visita aos túmulos no centro da cidade, volta-se à periferia, onde em frente ao Fogo Sagrado é realizado um culto, liderado pelo Bispo Supremo da igreja Oruuano. Me perguntei a todo tempo o que era aquilo: sincretismo ou domínios diferentes do mundo herero? Um esforço interessante para um próximo ensaio.

Ao que parece, a igreja se estabelece como a igreja "oficial" herero, mas (tal como o fenômeno que ocorre com outras igrejas - católica e protestante - em outras regiões do globo) podemos supor que sua capacidade de adquirir fiéis é problemática. Talvez novas articulações sincréticas sejam necessárias, agora não mais como resistência. É preciso, outra vez, reinventar: é preciso sincretizar.

$\overline{\text { Josué Tomasini Castro é bacharel em Ciências Sociais pela }}$ Pontifícia Universidade Católica do Rio Grande do Sul e mestrando 
1 O trajeto do texto é similar àquele percorrido por Johannes Fabian em seu Performance and Power (1990), onde ele procurou entender o sentido da frase "the power is eaten whole". Agradeço os comentários e críticas do professor Pierre Sanchis, da Universidade Federal de Minas Gerais, de Suzana C. Bornholdt, doutoranda em Ciências da Religião na Universidade de Lancaster, e dos pareceristas anônimos.

2 Na bibliografia clássica dos estudos de religião em sociedades africanas tal sistema seria denominado "culto aos ancestrais". Em meu texto procurarei fugir um pouco destas conotações de crença, seguindo uma tendência vigente desde pelo menos a década de 1960. A tendência de que falo é aquela defendida por Robin Horton (1964, 1967), para quem os antropólogos cometem um erro de tradução ao dizer crença e não ciência (conhecimento) quando estudando muitas das sociedades africanas. No limite, seu argumento afirma que, na África, temos epistemologia e não crença e religião quando se trata da relação entre vivos e mortos, mundo visível e invisível. No que tange especificamente ao chamado "culto aos ancestrais" tomo o trabalho de Kopytoff (1971), que retoma o argumento de Meyer Fortes (1987[1965]), para quem tais sistemas eram manifestações das estruturas sociais de determinada sociedade. Fortes afirmava, no entanto, que essas manifestações eram projeções simbólicas do sistema social, como que o reflexo sagrado das relações no mundo dos vivos. Já o argumento de Kopytoff nos aponta a continuidade das relações sociais do mundo dos vivos ao mundo dos mortos. É a manutenção das relações entre pais e filhos (senioridade) e não a criação de um vínculo entre o profano e o sagrado (ancestralidade).

3 Sobre a possibilidade de trazer para a discussão os diálogos com outros interlocutores, acreditei não ser necessário dadas as minhas pretensões com este ensaio. Tal esforço, no entanto, foi empreendido em minha monografia de graduação, “Discursos Herero sobre uma África Cristã: contribuições antropológicas para a compreensão de fenômenos sincréticos" (Castro 2006).

4 Esforço já conhecido na literatura antropológica pelos trabalhos de Victor Turner (1960), Jean-Paul Dumont (1978) e Vicent Crapanzano (1980), entre outros.

5 Apenas para citar alguns: Meyer Fortes entre os Tallensi (1983 e 1987), Evans-Pritchard entre os Azande (1976), Victor Turner entre os Ndembu (1957), Jean e John Comaroff entre os Tshidi (1985 e 1991).

7 Uso o termo aqui no sentido de um processo de socialização continuamente reformulado, de criação e recriação, absorção e liberação de sentidos no, do e para o mundo (Berger 1983). Ao afirmar que "no limite seria uma conversão", faço alusão ao trabalho de Herskovits, Linton e Redfield (1967 [1936]) no qual alguns pontos para o estudo de processos de aculturação são relacionados. Isso não significa que entenda a aculturação como um processo unilateral, ela é uma construção. Isto está claro para nós, mas não estava para aqueles que acreditavam na inevitabilidade do fim de uma lógica e sua subseqüente substituição por aquela dos colonizadores. Não quero dar a esta palavra um peso maior do que essas simples constatações históricas que acredito não servirem mais como aportes teóricos seguros e que, por isso, devem ser melhor problematizadas.

9 Claro está, no entanto, que este processo ocorre igualmente no universo simbólico daqueles que exercem o poder dominante. As reapropriações não são unilaterais. Em muitos momentos, as práticas religiosas autóctones foram tomadas de empréstimo por missionários para fortalecer também o discurso cristão e seus ímpetos proselitistas. Terence Ranger (1976) exemplifica isso bem. 
10 Entendo repertório como um "grupo de elementos aos quais o fiel [de uma religião, no caso] pode recorrer para entender sua realidade. Estes elementos [...] estariam divididos em pequenas caixas conceituais, onde os indivíduos organizariam seus significados, os quais, com o decorrer do tempo, seriam modificados, sendo que novos elementos poderiam ser adicionados e outros removidos" (Castro 2006). Usando este conceito na análise dos fenômenos em questão teremos, tal como Gustavo Benavides defende, sincretismo como "o ordenamento natural de um repertório de elementos os quais um fiel pode escolher", sendo que a política dos fenômenos sincréticos está justamente na "luta por possuir, controlar e transformar os significados simbólicos" dos elementos presentes nos repertórios de um grupo (2005:153-5).

12 Falar de "tradições" certamente é uma proposta arriscada; assim, parece adequado fazer uma breve exposição de alguns cuidados necessários no uso deste termo. Uma primeira observação deve ser feita no sentido de desmistificar a idéia da pureza de uma tradição: todas as tradições são inventadas e, assim sendo, é impossível alcançarmos o ponto original onde as tradições iniciaram suas "épocas"; as tradições estão sendo sempre recriadas, consciente e inconscientemente (Hobsbawm \& Ranger 2002 [1997]). Outro cuidado está em não imaginarmos esta "tradição" como todo-poderosa e onipresente, agindo da mesma forma sobre todos e/ou como se todos respondessem a suas demandas da mesma forma. No entanto, é possível perceber algumas reações, formas de fazer as coisas (tal como em Geertz [1995], quando este fala de "cultura" - e certamente é possível problematizar mais esta questão) que são aceitas por uma maioria ou são ao menos legitimadas tanto pelos insiders como pelos outsiders como uma propriedade particular de determinado grupo. Aceitar isso não significa inevitavelmente aceitar aqueles preceitos problemáticos.

13 Vale um pequeno comentário em relação a estes últimos parágrafos e à nota 2 acima, na qual defendo a não-sacralidade dos ditos complexos de ancestralidade. Ora, no limite, aquelas reflexões significam afirmar que não é de religião que deveríamos estar falando. A dificuldade em levar isso a cabo em uma análise de cunho bibliográfico-histórico é o uso corrente e mais do que aceito de termos relacionados a um certo idioma (cristão) de religião. Assim, a nota anterior deverá ser pensada como um incentivo futuro, algo de que podemos tomar posse para re-pensar nossos elementos de campo. Para os contornos deste ensaio ela se limita a esclarecer uma opinião do autor que, assim como Kopytoff, vê senioridade e não ancestralidade, secularidade e não sagrado ao refletir sobre o Fogo Sagrado.

14 Sabe-se também, ainda com Berger, a respeito dessa empreitada conceitualizante, que as "definições não podem ser, por sua própria natureza, 'verdadeiras' ou 'falsas', podem apenas ser mais ou menos úteis" (1985:181).

16 A descrição que farei está baseada naquilo que ouvi durante as conversas e entrevistas realizadas durante meu trabalho de campo e não em outros trabalhos sobre a religião herero (de fato são poucos os trabalhos que fazem uma discussão mais completa do ritual, cito alguns: Abati 1999; Gibson 1956; Wallace 2003). Outros esforços etnográficos poderão definir o Fogo Sagrado de forma diferente, mas isso é possível pelo fato de que as pesquisas foram realizadas em momentos e locais distintos. Assumindo que as "tradições" estão em constante modificação, sendo regularmente reinventadas, não é estranho constatar tais diferenças. Meu esforço está posto a partir de minha experiência restrita aos moradores de Okondjatu e, por isso, seria imprudente descrever o Fogo Sagrado de forma diferente de como ele me foi explicado. Um esforço comparativo entre essas diferentes formas já está em elaboração.

17 É interessante perceber que nas estruturas de autoridade de muitas sociedades africanas o poder de seus líderes alcança um valor que transcende as estruturas físicas do visível e palpável. Ele é reconhecido como uma substância que não pode ser outorgada (tal como era feito nas distribuições de títulos coloniais aos "intermediários tribais" entre comunidades locais e forças coloniais) e que não está restrita a um local ou relação específica: ele é difuso, se apresenta e se impõe em todos os diferentes níveis de relações sociais dentro de uma comunidade (Fortes 1983, 
1987; Kopytoff 1971; Trajano 1994).

18 Localizadas no centro do vilarejo, as cabanas eram os locais onde algumas mulheres vendiam carne e seus fatcakes.

19 "Vem aqui", em Otjiherero.

21 Uma breve observação deve ser feita, apenas para esclarecer uma confusão que demorei alguns dias para resolver. Meu comentário havia sido sobre a igreja da Estrela de São Josué - à qual sua igreja também se opõe - e ele entendeu que eu estava comentado a respeito da igreja à qual ele pertence - a igreja Oruuano; eu falei sobre A e ele respondeu sobre B. Mais tarde, como disse acima, descobri que Caspa era um dos líderes da igreja Oruuano e, ao descobrir isso, fiquei imaginando o que o levaria a afirmar ser uma outra igreja que não a sua a verdadeira igreja tradicional herero. 0 fato foi esclarecido quando, alguns dias depois, em uma entrevista realizada com ele, as mesmas afirmações foram repetidas, fortalecendo a minha hipótese de que o que ocorreu naquele dia foi um perigoso descuido auditivo.

26 Como resultado desse envolvimento político, a Sociedade teve um papel importante no início dos debates, na Alemanha, sobre o estabelecimento de uma colônia imperial alemã.

27 Referências importantes ao conflito são feitas em Alexander (1988), Bridgman (1981), Drechsler (1980), Gewald (1999), Gewald \& Silvester (2001), Ngavirue (1997), Prein (1994) e Stone (2007).

28 Digo inovadora porque antes da chegada dos primeiros colonizadores na região o que se entendia por herero - na época (década de 1850) conhecidos como Damara - eram grupos pastoris que, a partir do século XVI, chegaram à Namíbia via o rio Kunene, ao norte, e se estabeleceram nas áreas centrais da região, perto do que hoje é Windhoek e Okahandja, e também ao norte, nas atuais fronteiras do país com a Angola. Como percebemos nas etnografias de grupos pastoris na África, tais sociedades caracterizam-se por uma forte descentralização e alta mobilidade, o que se aplica igualmente aos hereros na Namíbia. Assim, a centralização de uma liderança era restrita aos limites do Ozonganda, um assentamento sob a liderança de um Omukuru, chefe de um clã patrilinear. O poder deste chefe em concentrar e adquirir aderentes estava completamente limitado à satisfação que os últimos sentiam sob seu cuidado e caso algo thes desagradasse eles não hesitariam em "votar com seus pés". Assim, os discursos nacionalistas herero pós-colonização alemã eram formas completamente novas de se pensar enquanto grupo (para um melhor entendimento destas questões ver Castro 2008).

29 Oruuano, em Otjiherero, significa "comunhão".

30 Talvez a palavra "apropriação" seja melhor para definir este movimento de incorporação de elementos cristãos ao sistema nativo ou, inversamente, de elementos nativos ao sistema cristão, já que não se deve presumir que todos os herero fossem convertidos à religião cristã.

31 Conforme o artigo 395: “O Sagrado Concílio, retomando os ensinamentos do Concílio Vaticano I, declara que há 'duas ordens de conhecimento' distintas, a saber, a da fé e a da razão. Portanto a igreja não pode absolutamente impedir que 'as artes e disciplinas humanas usem de princípios e métodos próprios, cada uma em seu campo'. Por isso, 'reconhecendo a justa liberdade', afirma a legítima autonomia da cultura humana e particularmente das ciências" (Vier 1999:211).

32 Vale lembrar aqui que estes devem ser entendidos como "tributos de submissão" (Vansina 1962). 


\section{REFERÊNCIAS BIBLIOGRÁFICAS}

ABATI, Francisco G. 1992. "La Religión de los Himbas". Revista de Antropología Social 1:151-66 (disponível em http://dialnet.unirioja.es/servlet/articulo?codigo $=157852$.

ALEXANDER, Neville. 1988. "The Namibian War of Anti-colonial Resistance, 1904-7". In Brian Wood (ed.) Namibia 1884-1984: Readings on Namibia's History and Society. London: Namibia Support Committee \& United Nations Institute for Namibia.

APTER, Andrew. 2005 [1999]. "Herskovits's Heritage: rethinking syncretism in the African diaspora". In Anita Leopold \& Jeppe Jensen (eds.) Syncretism in Religion: a reader. New York: Routledge.

. 1999. "Africa, Empire and Anthropology: a philological exploration of anthropology's heart of darkness". Annual Review of Anthropology 28: 577-98.

BALANDIER, Georges. 1955. Sociologie Actuelle de l'Afrique Noire: dynamique des changements sociaux en Afrique Centrale. Paris: Presses Universitaires de France.

BENAVIDES, Gustavo. 2005. "Syncretism and Legitimacy in Latin American Religion". In Anita Leopold \& Jeppe Jensen (eds.) Syncretism in Religion: a reader. New York: Routledge.

BERGER, Peter. 2004 [1985]. O Dossel Sagrado: elementos para uma teoria sociológica da religião. São Paulo: Paulus.

BERGER, Peter \& Thomas Luckmann. 2002 [1983]. A Construção Social da Realidade. Petrópolis: Vozes.

BRIDGMAN, Jon. 1981. The Revolt of the Hereros. Berkeley, Los Angeles \& London: University of California Press.

CASTRO, Josué T. 2006. Discursos Herero sobre uma África Cristã: contribuições antropológicas para a compreensão de fenômenos sincréticos. Monografia de Graduação em Ciências Sociais. Porto Alegre: Pontifícia Universidade Católica do Rio Grande do Sul, Faculdade de Filosofia e Ciências Humanas.

. 2008. "Memória e Identidade nas Comemorações Herero na Namíbia". Comunicação apresentada no GT 19 - "Entre Fronteiras e Disciplinas: estudos de África e Caribe". Caxambu (MG): 32ª Reunião Anual da Anpocs.

COMAROFF, Jean. 1985. Body of Power, Spirit of Resistance. Chicago: The University of Chicago Press. 
COMAROFF, Jean \& John Comaroff (eds.). 1999. Civil Society and the Political Imagination in Africa. Chicago: The University of Chicago Press.

. 1991. Of Revelation and Revolution: christianity, colonialism and consciousness in South Africa (volume 1). Chicago: The University of Chicago Press.

CRAPANZANO, Vicent. 1980. Tuhami: portrait of a Moroccan. Chicago: The University of Chicago Press.

DIERKS, Klaus. 2002. Chronology of Namibian History. Windhoek: Namibian Scientific Society.

DRECHSLER, Horst. 1980 [1966]. "Let Us Die Fighting": the struggle of the Herero and Nama against German Imperialism (1984-1915). London: ZED Press.

DREYER, Ronald. 1994. Namibia and Southern Africa. Regional Dynamics of Decolonization, 1945-1990. New York: Routledge.

DROOGERS, André. 2005. "Syncretism, Power, Play". In Anita Leopold \& Jeppe Jensen (eds.) Syncretism in Religion: a reader. New York: Routledge.

DROOGERS, André \& Sidney M. Greenfield. 2001. "Introduction: a symposium”. In A. Droogers \& S. M. Greenfield (eds.) Reinventing Religions: syncretism and transformation in Africa and the Americas. New York: Rowman \& Littlefield Publishers.

DUMONT, Jean-Paul. 1978. The Headman and I. Texas: University of Texas Press.

ELIAS, Norbert. 1990 [1939]. O Processo Civilizador (v. 2). Rio de Janeiro: Jorge Zahar Editor. 1993 [1939]. O Processo Civilizador (v. 1). Rio de Janeiro: Jorge Zahar Editor.

FABIAN, Johannes. 1990. Power and Performance: ethnographic explorations through proverbial wisdom and theater in Shaba, Zaire. Wisconsin: The University of Wisconsin Press.

FERRARI, Franco. 2003. "Plutarco: platonismo e tradição". In F. Ferrari (org.) Filósofos da Antiguidade II. São Leopoldo: Unisinos.

FERRETTI, Sérgio. 1995. Repensando o Sincretismo. São Paulo: Edusp.

FORTES, Meyer. 1987 [1965]. "Ancestor Worship in Africa". In Religion, Morality and the Person: Essays on Tallensi Religion. Cambridge: Cambridge University Press. 
. 1983. Oedipus and Job in West African Religion. Cambridge: Cambridge University Press.

FRAZER, Sir James. 1993 [1890]. The Golden Bough. London: Wordsworth Reference.

GADAMER, Hans-Georg. 2004 [1975]. Truth and Method. London / New York: Continuum.

GEWALD, Jan-Bart. 1999. Herero Heroes: a socio-political history of the Herero of Namibia, 1890-1923. Oxford: James Currey.

GEWALD, Jan-Bart \& Jeremy Silvester. 2003. Words Cannot be Found: german colonial rule in Namibia. An Annotated Reprint of the 1918 Blue Book. Leiden-Boston: Brill.

GIBSON, Gordon. 1956. "Double Descent and its Correlates among the Herero of Ngamiland". American Anthropologist New Series 1(58): 109-39.

GEERTZ, Clifford. 1995. Tras los Hechos. Barcelona: Paidós.

2003 [1973]. A Interpretação das Culturas. Rio de Janeiro: LTC.

HERSKOVITS, Melville J. 1924. "A Preliminary Consideration of the Culture Areas of Africa". American Anthropologist New Series 26(1): 50-63.

1962. The Human Factor in Changing Africa. New York: Vintage Books.

1973. Antropologia Cultural II. São Paulo: Mestre Jou.

HERSKOVITS, Melville; Ralph Linton; Robert Redfield. 1967 [1936]. "Memorandum for the Study of Acculturation". In Paul Bohannan \& Fred Plog (eds.) Beyond the Frontier: social process and culture change. Garden City / Nova York: The Natural History Press.

HORTON, Robin. 1964. "Ritual Man in Africa”. Africa 34: 85-104.

. 1967. “African Traditional Thought and Western Science". Africa 51(1): 50-71 and 155-187.

KEMPF, Wolfgang. 1994. "Ritual, Power and Colonial Domination: male initiation among the Ngaing of Papua New Guinea". In Rosalind Shaw \& Charles Stewart (eds.) Syncretism/ Anti-Syncretism: the politics of religious synthesis. Nova York: Routledge. 
LEOPOLD, Anita M. \& Jeppe S. Jensen (eds.). 2005. Syncretism in Religion: a Reader. Nova York: Routledge.

MAUSS, Marcel. 2003 [1904]. "Esboço de uma Teoria Geral da Magia”. In Sociologia e Antropologia. São Paulo: Cosac \& Naify.

NGAVIRUE, Zedekia. 1997 [1972]. Political Parties and Interest Groups in South West Africa (Namibia): a study of a plural society. Basel: Basler Afrika Bibliographien.

PREIN, Philipp. 1994. "Guns and Top Hats: African resistance in German South West Africa, 1907-1915". Journal of Southern African Studies 20(1):99-121.

OLIVEIRA, João Pacheco de. 1999. Ensaios em Antropologia Histórica. Rio de Janeiro: UFRJ.

OLIVEIRA, Roberto Cardoso de. 1981 [1964]. O Índio e o Mundo dos Brancos. Brasília: Universidade de Brasília.

EVANS-PRITCHARD, E. E. 2002 [1940]. Os Nuer. São Paulo: Ed. Perspectiva.

2005 [1976]. Bruxaria, Oráculos e Magia entre os Azande. Rio de Janeiro: Jorge Zahar Editor.

RANGER, Terence. 1976. "Missionary Adaptation of African Religious Institutions: the Masasi case". In Isaria Kimambo \& Terence Ranger (eds.) The Historical Study of African Religion. Los Angeles: University of California Press.

RIBEIRO, Darcy. 1970. Os Índios e a Civilização Brasileira. Rio de Janeiro: Civilização Brasileira.

RUDOLPH, Kurt. 2005. "Syncretism: from theological invective to a concept in the study of religion". In Anita M. Leopold \& Jeppe S. Jensen (eds.) Syncretism in Religion: a Reader. Nova York: Routledge.

SAHLINS, Marshall. 1997a. “O ‘Pessimismo Sentimental' e a Experiência Etnográfica: por que a cultura não é um 'objeto' em via de extinção (Parte I)". Mana 3(1): 41-73.

. 1997b. “O 'Pessimismo Sentimental' e a Experiência Etnográfica: por que a cultura não é um 'objeto' em via de extinção (Parte II)". Mana 3(2): 103-50. . 2003 [1985]. Ilhas de História. Rio de Janeiro: Jorge Zahar Editor.

SANCHIS, Pierre. 1994. "Para não Dizer que não Falei em Sincretismo". Comunicação do ISER 45:5-11.

SHAW, Rosalind \& Charles Stewart. 1994. "Introduction: problematizing syncretism". In Syncretism/AntiSyncretism: the politics of religious synthesis. Nova York: Routledge.

STONE, Dan. 2007. "White Men with Low Moral Standards? German Anthropology and the Herero genocide". In A. Dirk Moses \& Dan Stone (eds.). Colonialism and Genocide. New York: Routledge. 
TRAJANO Filho, Wilson. 1994. “O Poder da Invisibilidade”. Série Antropologia 160. Brasília: UnB. . 1998. Polymorphic Creoledom: The creole society of Guinea-Bissau. Ph.D. Dissertation. Philadelphia: University of Pennsylvania.

TURNER, Victor. 1960. “Muchona the Hornet, Interpreter of Religion. In Joseph B. Casagrande (ed.) In the Company of Man: twenty portraits of anthropological informants. New York: Harper \& Row. 1996 [1957]. Schism and Continuity in an African Society. Oxford \& Washington, D.C.: Berg.

TYLOR, Edward B. 1970 [1871]. Religion in Primitive Culture. Nova York: Harper Torchbook.

VANSINA, Jan. 1962. “A Comparison of African Kingdoms". Africa 32:324-335.

VIER, Frei Frederico (coord.). 1999. Compêndio do Vaticano II: constituições, decretos e declarações. Petrópolis: Vozes.

WALLACE, Marion. 2003. "'Making Tradition': healing, history and ethnic identity among Otjiherero-Speakers in Namibia, c. 1850-1950". Journal of Southern African Studies 2(29):355-72. 


\section{Sincretismo e Resistência: o caso africano da igreja Oruuano}

\section{RESUMO}

No início do século XIX, os Herero, povo situado na África Subsaariana, foram confrontados com o colonialismo europeu. Neste encontro seu sistema religioso de culto aos ancestrais foi duramente combatido pelo luteranismo alemão difundido por missionários e por fiéis recém ingressados no território, responsáveis pelo início de um longo e complicado processo de cristianização. A constante diabolização da tradição herero e seu enfraquecimento iminente resultaram no surgimento de focos de resistência política e cultural. Destes focos nasce a igreja Oruuano, a objetivação da resistência da minoria dominada. Com base em trabalho etnográfico realizado na Namíbia, no vilarejo de Okondjatu, entre o povo herero, pretend discutir alguns aspectos gerais deste movimento A partir de narrativas herero, este artigo procura entender as características sincréticas da igreja Oruuano, bem como alguns aspectos gerais percebidos por seus fiéis que fazem com que ela seja aqui entendida como um movimento de resistência identitária e cultural.

PALAVRAS-CHAVE: Herero, colonialismo, sincretismo, resistência.

\section{Sincretism and Resistance: the african example of the Oruuano church}

\section{ABSTRACT}

In the beginnings of the $19^{\text {th }}$ century, the Herero, a people living in subsaarian Africa, were confronted with European colonialism. On this clash their religious system based on ancestors' worship was hardly threatened by German Luteranism, spread by missionaries and followers newly arrived at the territory, which were responsible for a long and complicated process of Christianization. The constant demonization of herero's tradition and its imminent loss of power resulted in the genesis of some political and cultural focuses of resistance. From these emerged the Oruuano Church, the resistance objectification of the dominated minority. Based on fieldwork conducted in the village of Okondjatu, Namíbia, among herero people, this paper intends to discuss some general aspects of this resistance movement. Working with herero narratives, effort is made to understand sincretic characteristics of the Oruuano Church and some of its general aspects issued by its followers. It is suggested that the Oruuano Church might be understood as an identity and cultural resistance movement.

KEYWORDS: Herero, colonialism, syncretism, resistance.

Recebido em 21/01/2008

Aprovado em 09/12/2008 
158 